\title{
Fertility and economic instability: the role of unemployment and job displacement
}

Emilia Del Bono

Institute for Social and Economic Research University of Essex

\section{Andrea Weber}

University of Mannheim

\section{Rudolf Winter-Ebmer}

University of Linz

No. 2014-06

February 2014

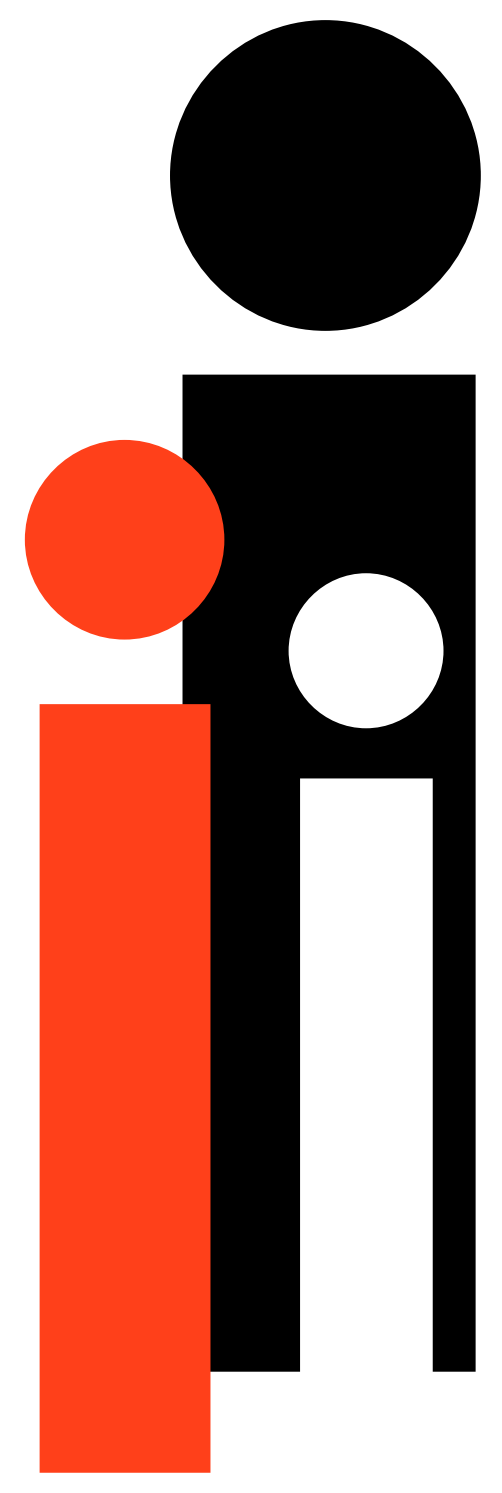

INSTITUTE FOR SOCIAL \& ECONOMIC RESEARCH 


\section{Non-technical summary}

Many recent empirical studies show evidence of a strong negative relationship between fertility and unemployment at the aggregate as well as at the individual level. Unemployment might be capturing only one aspect of a more general problem though; a problem we may call labor market "instability" and that could be at the roots of the low levels of fertility observed in many European countries. To date, however, attempts to analyse how labor market institutions that generate or increase instability - such as temporary contracts, part-time work, or flexible jobs - impact aggregate fertility rates or a woman's propensity to have a child have been rather few and far between.

In this paper we analyse the relationship between unemployment and fertility using data for Austria during the period between 1990 and 1998. The main empirical challenge we face is in identifying the causal impact of unemployment on fertility. There could be a problem of reverse causality, if (for example) women planning to have a child in the near future are more likely to lose their job, either because they become less productive or because managers might target these women for temporary layoffs. In addition, there might be unobservable characteristics determining unemployment and fertility at the same time. For instance, women with a high propensity to have children might seek less demanding jobs and careers with lower returns and higher employment uncertainty. Alternatively, it is possible that women who plan to start a family might seek more stable careers and job security. In all these cases the OLS coefficient on unemployment could be biased.

In order to address this problem we use job displacement caused by a firm closure to identify changes in unemployment that are independent of individual characteristics and circumstances. We then try to disentangle the effect of unemployment per se from the effect of an involuntary job separation. That is, we investigate whether fertility is mainly affected by the loss of earnings due to not being in employment, or is also responsive to the change in career prospects and the effort required to find a new job which accompany any involuntary job separation. Our identification strategy is based on two specific features of the labor market we study. First, a job loss due to a firm closure is not always followed by a spell of unemployment; indeed more than $2 / 3$ of displaced women in this study experience a job-to-job transition. Second, individual variation in unemployment duration in Austria is largely due to seasonal and industry-specific effects. This allows us to include in our analysis an indicator for firm closure as well as a variable capturing the incidence or the length of the individual unemployment spell.

Our results show that a job separation cause by a firm closure exerts a negative effect on fertility, while the incidence and duration of unemployment has no additional impact. We also document stronger (more negative) effects of displacement for women with higher pre-displacement wages and higher pre-displacement wage growth. We interpret this finding as evidence that career and employment considerations are very important determinants of fertility decisions and matter more than short-run income effects while being unemployed. From a policy perspective this study is important as it provides new evidence that labour market institutions associated with higher uncertainty about employment and lower career and promotion opportunities - such as temporary, part-time, or zero-hours contracts - can significantly reduce women's demand for children. 


\title{
Fertility and Economic Instability: The Role of Unemployment and Job Displacement *
}

\author{
Emilia Del Bono ${ }^{\dagger}$ Andrea Weber ${ }^{\ddagger}$ Rudolf Winter-Ebmer ${ }^{\S}$
}

December 16, 2013

\begin{abstract}
In this paper we study the separate effects of unemployment and job displacement on fertility in a sample of white collar women in Austria. Using an instrumental variables approach we show that unemployment incidence as such has no negative effect on fertility decisions, but the very fact of being displaced from a career-oriented job has. Fertility rates for women affected by a firm closure are significantly below those of a control group, even after six years, and this is so irrespective of the incidence or the duration of the associated unemployment spell.
\end{abstract}

Keywords: fertility, unemployment, firm closures, human capital JEL classification: J13, J64, J65, J24

\footnotetext{
*We are grateful to workshop participants in Essen and Milano. This project received funding from the Austrian Science Fund (NRN Labor Economics and the Welfare State). Emilia Del Bono acknowledges the support provided by the ESRC Centre on Micro-Social Change at ISER (grant RES518-28-001). All errors and opinions are the authors' sole responsibility.

${ }^{\dagger}$ ISER, University of Essex, and IZA, Bonn. E-mail: edelbono@essex.ac.uk

${ }_{\ddagger}^{\ddagger}$ University of Mannheim, IZA, Bonn and CEPR. E-mail: a.weber@uni-mannheim.de

${ }^{\S}$ University of Linz, IHS Vienna, IZA, Bonn and CEPR. E-mail: rudolf.winterebmer@jku.at
} 


\section{Introduction}

Standard microeconomic models of fertility predict that the demand for children should be negatively correlated to levels of female activity and that during periods of high unemployment the fall in the opportunity costs of childbearing should induce an increase in the number of births. In other words, fertility should be counter-cyclical (Butz and Ward, 1979). Empirical observations were consistent with this hypothesis throughout the 70s and 80s (Heckman and Willis, 1975), but by the end of the 90s the cross-country correlation between fertility and female labor market activity turned positive and many European countries witnessed rapid declines in fertility rates and rising levels of unemployment (Bettio and Villa, 1998; Ahn and Mira, 2002; Engelhardt and Prskawetz, 2004). Pro-cyclical fertility emerged as a new empirical regularity and numerous studies aimed at analysing the effect of unemployment on fertility showed a strong negative relationship between these two variables at the aggregate as well as at the individual level. ${ }^{1}$

The literature which relates labor market conditions to fertility has always stressed the idea that unemployment is only one aspect of a more general problem, a problem we may call labor market "instability" and that might be at the roots of the recent trends in fertility rates observed in many European countries. Studies using aggregate unemployment rates to explain individual fertility behavior are to some extent capturing this instability as well. High aggregate unemployment may increase individual unemployment incidence, or the risk of losing a job in the near future, or at the same time reduce the likelihood of future wage growth (Adsera and Menendez, 2011). However, attempts to isolate these different mechanisms or to identify the effects of labor market institutions that increase instability - such as temporary contracts, part-time work, or flexible jobs - have been rather isolated (De la Rica, 2005; Gonzalez and Jurado-Guerrero, 2006;

\footnotetext{
${ }^{1}$ See Adsera (2005) for a study of the effects of aggregate unemployment rates on fertility rates across a number of European countries. Perry (2003) shows that in the US college-educated females' fertility behaves pro-cyclically whereas Dehejia and Lleras-Muney (2004) report several examples of pro-cyclical fertility, mainly in more developed countries. Kravdal (2002) for Norway and Meron et al. (2002) for France show a negative effect of individual unemployment experience on fertility, while GutierrezDomenenech (2008) studies its impact on fertility timing and marriage behaviour in Spain. See also Sobotka et al. (2011) for a recent review on the effect of recessions on fertility.
} 
Adsera, 2011)..$^{2}$

In this paper we analyse the relationship between unemployment and fertility in Austria during the period between 1990 and 1998. In order to address the problem of endogeneity of unemployment we first use job displacement caused by a firm closure as a source of exogenous variation in unemployment. We then try to disentangle the effect of unemployment per se from the effect of an involuntary job separation. That is, we investigate whether fertility is mainly affected by the loss of earnings due to not being in employment, or is also responsive to the change in career prospects and the effort required to find a new job which accompany any involuntary job separation caused by a firm closure. In doing so, we explore the extent to which the negative relationship between fertility and unemployment documented in the literature is mainly driven by contingent income considerations, or reflects broader issues related to long-term career prospects and uncertainty about employment opportunities.

Our identification strategy is based on two specific features of the labor market we study. First, an involuntary job loss due to a firm closure is not always followed by a spell of unemployment; indeed more than $2 / 3$ of displaced women in this study experience a job-to-job transition. Second, individual variation in unemployment duration in Austria is largely due to seasonal and industry-specific effects (Del Bono and Weber, 2008). This allows us to include an indicator for firm closure as well as a variable capturing the incidence or the length of the individual unemployment spell in our empirical model of fertility. To account for the endogeneity of unemployment, we instrument the latter using interactions between firm closure and seasonal, geographical and temporal effects. This way we explicitly distinguish the effect of job displacement which operates through career and employment considerations from the effect of job displacement which operates through the loss of earnings caused by an unemployment spell.

Our results show that a job separation exerts a negative effect on fertility, while

\footnotetext{
${ }^{2}$ See Kohler and Kohler (2002), Ranjan (1999) or Kreyenfeld (2010) for studies trying to associate the fertility decline in (Eastern) Europe with general economic uncertainty.
} 
variation in unemployment induced by the firm closure does not have an additional impact. We also document stronger (more negative) effects of displacement for women with higher pre-displacement wages and higher pre-displacement wage growth. We interpret this finding as evidence that career and employment considerations are very important determinants of fertility decisions and matter more than short-run income effects while being unemployed. This evidence is in line with the results recently discussed in Del Bono et al. (2012).

From a policy perspective this study is important as it provides new evidence that labour market institutions associated with higher uncertainty about employment and lower career and promotion opportunities - such as temporary, part-time, or zero-hours contracts - can significantly reduce women's demand for children. The study also suggests that if career breaks are costly in terms of future earnings and employment opportunities irrespective of the length of the interruption, family policies which emphasise the importance of income support during periods of maternity leave might not be the best tool to reconcile motherhood with good labor market outcomes for women.

\section{Data and Empirical Setup}

Our analysis is based on the Austrian Social Security Database (ASSD) which covers all private sector workers between 1972 and 2007. The data include daily information on employment and unemployment status, total annual earnings paid by each employer, and various characteristics of the workers and their jobs (Zweimüller et al., 2009). Our definition of unemployment is based on registration status, i.e. it only includes periods in which individuals are receiving unemployment benefits. Eligibility for unemployment benefits is related to previous employment; as long as the woman has worked at least 52 weeks in the previous two years she is entitled to receive unemployment benefits of about $55 \%$ of her previous net income. ${ }^{3}$

\footnotetext{
${ }^{3}$ Eligibility for parental leave benefits follows similar rules, with the exception that mothers younger than 25 are eligible after having worked 26 weeks in the previous year. In Austria women who have
} 
The availability of employer identifiers creates a linked worker-firm component in the ASSD, which we exploit to define firms. In our sample we consider firms that have at least one employed worker on the payroll on any of four sampling dates (February 10, May 10, August 10, and November 10) over the years 1990 to 1998. Firm exit dates are defined as the last quarter date in which a firm employs at least one worker. To define firm closures we apply three selection criteria. First, we exclude firm exits, where more than $50 \%$ of the workforce in the last year jointly transits to the same new employer. Second, we exclude firms operating in agriculture, construction, and tourism industries. These sectors are characterized by a high share of seasonal employment which makes it difficult to identify firm entries and exits. Third, we only consider firms with five or more employees on one quarter date during 1972-2002, and restrict the sample to firms with more than 3 workers in the closing quarter, because based on the worker-flow approach we cannot identify firm closures for very small firms.

Based on this sample of firms we consider all women between 18 and 35 years, employed in white-collar jobs between quarter 1/1990 and quarter 4/1998, and having at least one year of tenure in the current firm. These women will therefore all have equal entitlement to unemployment and parental benefits. We focus on women working in white collar jobs, because for them firm-specific human capital or ability are likely to be more relevant determinants of productivity and an involuntary job separation will be more costly (see also the discussion in Del Bono et al. (2012)). By contrast, blue-collar jobs are relatively rare among women in Austria, and confined to manual occupations in low ranking positions in the production sector, with modest salaries and high job-turnover even in the absence of firm closure. Having said that, white-collar jobs may include career jobs with high earnings (growth) prospects as well as other more dead-end jobs in the service sector. We will later differentiate between different types of white-collar jobs.

children are entitled to 16 weeks of maternity protection, which is usually divided into 8 weeks before and 8 weeks after birth, and up to two years of parental leave. The maternity protection period is paid at $100 \%$ of the previous salary, the remaining period is paid at a flat rate of 408 Euros per month. 
We define as displaced all women working in a closing firm the quarter before closure and as control all women who are not affected by a firm closure, i.e. working in a control firm in any quarter, which we call the reference quarter. Because of the downsizing and restructuring in the period prior to firm closure, a non-randomly selected pool of workers may be left at the closing date. To deal with selection over the firm closure process, the literature typically suggests to include worker separations from a longer period prior to the firm closure date (Dustmann and Meghir, 2005; Eliason and Storrie, 2006). This type of solution turns out to be infeasible in our application, however. All women who give birth are required by law to leave their jobs for at least four months, which means that we must avoid definitions of displacement that potentially include voluntary quits. ${ }^{4}$ Finally, in order to make the empirical analysis more manageable we take a random $5 \%$ sample from the group of control women. The final sample consists of 6,431 observations of women in the displaced group and 157,884 observations of women in the control group.

To derive a measure of fertility for every woman in the labor force, we merge the ASSD with child benefit records from the Ministry of Finance. As take up of child benefits is almost universal in Austria, and applies to all children up to age 18, we have access to all births from 1975 to 2005 . Our outcome of interest is the number of births per woman after the reference date. This excludes births occurring within six months of the reference date, i.e. we do not consider women who are pregnant at the time of displacement. Since job displacement might affect the total number of children as well as the timing of fertility, we look at the path of birth rates up to six years following the reference date.

To show the effects of firm closure on labor market and fertility outcomes, we start with a graphical event study, where we pool all observations at the reference date and plot the means of the outcome variables each quarter before and after the reference date separately for the displaced and control groups. Looking at the period before

\footnotetext{
${ }^{4}$ Using the same data employed in this study, Del Bono et al. (2012) show evidence that the labor market and fertility histories of women employed in the firm one year before closure do not differ significantly from those of women in the displaced group.
} 
the reference date establishes the a priori comparability of different groups. This is an important check as closing firms may differ from surviving firms and women with different unobserved characteristics might select into more or less "risky" firms in terms of their likelihood to close down.

Figure 1 shows the effects of firm closure on labor market outcomes. We plot days employed per quarter in the 20 quarters before and up to 12 quarters after the reference date in the first graph. Employment for both the displaced and control groups is at 100\% in quarters -3 to 0 due to our one year tenure requirement. Before that, employment is lower in both groups. Notably, the displaced group has smaller employment in all quarters, but the difference is minor, accounting for two or three days per quarter at most. After the reference date we see a huge drop in employment in the displaced group to an employment rate of approximately $75 \%$. Employment in the control group declines gradually, reflecting the loose labor market attachment of young women in Austria. By the end of the third year after the reference date there is still a significant difference in employment between the displaced and control women. The reverse picture is shown for unemployment in the second graph. ${ }^{5}$ While unemployment is low in both groups before the reference date it shoots up after displacement. The results for monthly earnings (including zeros if the individual is not employed), shown in the third graph closely resemble employment, which indicates that earnings losses from job displacement are mostly driven by lower employment rather than wage reductions. Finally, wages for employed workers show that although there are small wage losses after plant closure, these are negligible relative to losses due to unemployment.

Figure 2 plots the average yearly numbers of births in the 14 years before the reference date and 10 years afterward. The mean number of births per year is age-adjusted, i.e. it is based on the residuals of a regression of the number of births on age of the mother and its square. The graph shows that the average number of births per woman decreases rapidly up to the reference date, when it becomes zero, and then shoots up dramatically.

\footnotetext{
${ }^{5}$ Unemployment is defined as being in receipt of unemployment benefits, and not simply as a period of non-employment.
} 
This pattern is a consequence of the fact that we select only women with at least one year of tenure at the reference date. This means that all women must have been working during the year before closure and therefore, by construction, they cannot have any children between year -1 and year 0 . As these women are also more likely to have been in employment in the periods leading to the reference date, we observe a decreasing birth rate in the years preceding closure. The jump in the probability of a birth after the reference date is also a consequence of our tenure requirement. Conditional on not having had a birth in the last year, these women are more likely to have a child in the following period. This graph nicely shows the strong similarity of displaced and control groups before the reference date. The most interesting feature in Figure 2, however, is the difference in fertility between displaced and control women after job loss, which shows very clearly that fertility is lower after a plant closure.

Table 1 compares the characteristics of women in the displaced group and in the control group. Displaced and control women are remarkably similar in age, nationality, total labor market experience, age at labour market entry, previous earnings (up to four years before the reference year), and previous employment (up to four years before the reference year), while they differ somewhat in terms of tenure, apprenticeship status and number of previous children. None of these differences are statistically significant. Nevertheless, all our regression results will take these characteristics into account. We do not consider here differences in firm characteristics, as we find that these are usually not useful to capture differences between our treated and control groups and including them in the regressions makes very little differences to the results. ${ }^{6}$

\footnotetext{
${ }^{6}$ Our checks show that using propensity scores weights constructed using individual characteristics helps to reduce further the (small) pre-displacement differences seen in Figure 1 and 2, and balance the treated and control sample. By contrast, propensity score weights constructed using firm characteristics only, have no effect on the differences between treated and control groups, either before or after displacement. In the interest of space, we do not report here these results, but refer to our companion paper (Del Bono et al., 2012) for a full discussion on these issues.
} 


\section{Career Interruption versus Unemployment}

Job displacement can affect fertility decisions through different channels. The first mechanism we consider here is whether it impacts fertility because it triggers a spell of unemployment (Figure 2). To begin with, we run the following fertility regression:

$$
F_{i}=\alpha+\gamma U_{i}+Z_{i} \beta+v_{i}
$$

where $F_{i}$ is the outcome measure, the number of births in the next three or six years. ${ }^{7}$ $U_{i}$ is a measure of unemployment, and $Z_{i}$ is a vector of covariates. We use two different variables to measure unemployment: an indicator variable equal to one if there is positive unemployment in the first year after the reference date (unemployment incidence), and the percentage of time the individual is unemployed during the first year after the reference date (unemployment duration).

Table 2 shows the relationship between fertility and unemployment in our data. In the top panel we report results for unemployment incidence while in the bottom panel we adopt a definition of unemployment duration. The first two columns of the table simply show the coefficient of an OLS regression of number of births - after three and six years - on the different measures of unemployment. As we can see in Panel A, a woman experiencing a spell of unemployment in the year after the reference date has much lower fertility than a woman experiencing no unemployment at all, and she will have 17.4 to $15.8 \%$ less children in the next three and six years, respectively. ${ }^{8}$ In Panel $\mathrm{B}$ we report the fertility effect of an increase in unemployment as a percentage of the first year after the reference date. The effect of longer unemployment during the first year is much smaller than the effect of the incidence of unemployment itself. The results indicate that a $10 \%$ rise in unemployment, which corresponds to a one standard deviation

\footnotetext{
${ }^{7}$ We conducted a similar analysis considering the probability of having another child in the next three or six years as the dependent variable. The results of this analysis are very similar to those presented here on the number of children because the main effects are found for women with no previous children.

${ }^{8}$ Standard errors are clustered at the individual level. Clustering at the firm level does not change the results in a meaningful way because of the small number of individuals employed within the same firm, particularly in the displaced group.
} 
increase, reduces fertility by 0.003 or $1.6 \%$ after three years. The effect is larger after six years, with a reduction in 0.01 children or $2.3 \% .^{9}$

There are, however, serious doubts about whether individual unemployment can be considered exogenous with respect to fertility. We could have a problem of reverse causality, if e.g. (planned) fertility decisions have an impact on unemployment. For example, women planning to have a child in the near future, might be more likely to lose their job, either because they become less productive or because managers might target these women for temporary layoffs. In addition, there might be unobservable characteristics determining unemployment and fertility at the same time. For instance, women with a high propensity to have children might seek less demanding jobs and careers with lower returns and higher employment uncertainty. Both biases would work in the same direction and induce a bias towards zero in the estimates. Alternatively, it is possible that women who plan to start a family might seek more stable careers and job security. In all these cases the OLS coefficient on unemployment could be biased away from zero.

In the next two columns we use exogenous variation in unemployment brought about by job displacement to obtain a consistent estimate of the effects of unemployment on fertility. The estimation is by two-stage least squares (2SLS), where the first stage regresses the relevant measure of unemployment on a dummy variable which assumes value 1 if the woman had been displaced by a firm closure at the reference date. ${ }^{10}$ The instrument has a strong influence on either definition of unemployment as shown by a t-test above 70 in the first stage regressions. Once again, estimation results indicate a significant and negative impact of unemployment on fertility. The magnitude of the effect is now two to three times larger than without controlling for the endogeneity of unemployment.

\footnotetext{
${ }^{9}$ The average number of children is 0.19 and 0.43 after three and six years since the reference date, respectively. See Table 1.

${ }^{10}$ The full results of this specification are available on request from the authors. Additional control variables are reported in the footnote to the table. Information about the partner or the marital status of the women was not available in the data. There is no information on level of educational qualification of the individual either, but this is captured by age of entry in the labour market and apprenticeship status.
} 
Although the standard errors also increase, we can in general significantly distinguish the 2SLS from the OLS estimates. Overall these results could be taken as evidence that unemployment has a true and non-negligible effect on fertility. Notice that the 2SLS estimates indicate that the OLS coefficients on unemployment are biased towards zero, which would suggest that women with a higher demand for children select themselves into jobs with a higher probability of unemployment.

The instrumental variables estimates in Table 2 show that based on variation due to an unexpected job loss, unemployment has a strong and negative effect on fertility. What we want to examine next is whether it is the job loss experience per se or the unemployment experience that lead to the observed decrease in fertility.

In order to test for the existence of an effect of job displacement which is independent of its consequences in terms of unemployment, we exploit the fact that a large share of women affected by firm closure do not experience any unemployment. In our sample of white-collar women, only $32.7 \%$ become unemployed in the first year after firm closure (as compared to $6.5 \%$ of the control group), i.e. more than $2 / 3$ of women in our displaced group experience a job-to-job transition. For these women the effect of firm closure on fertility should operate mainly through the disruption of career prospects and the need to find another job, while short-term income considerations should be less relevant. Our primary strategy is therefore to compare the fertility outcomes of women who experience unemployment and those of women who do not experience unemployment, after controlling for their displacement status, i.e. we run regressions of the following type:

$$
F_{i}=\alpha+\tau C_{i}+\gamma U_{i}+Z_{i} \beta+v_{i}
$$

including now $C_{i}$ as an indicator for firm closure as additional explanatory variable.

Regression models considering the separate effect of firm closure and unemployment on fertility are shown in Table 3. The first two columns report OLS estimates for different measures of fertility (three and six years after the reference date) and the two different measures of unemployment (top and bottom panel, as in Table 2). Both firm closure and 
unemployment exhibit a negative coefficient, so both tend to be associated with lower fertility. The incidence of unemployment, in Panel A, seems to have a larger negative impact on fertility than the experience of job displacement. According to Panel B, the impact of longer unemployment, say a one standard deviation increase, appears to be smaller than the effect of job displacement.

As before, unemployment experience should be considered endogenous. We therefore move on to a 2SLS specification, where we use the interaction between firm closure and dummies for years, quarters, regions and industries to predict unemployment. ${ }^{11}$ These 2SLS estimates are presented in columns 3 and 4 . Columns 5 and 6 show an alternative specification, which features a triple interaction between firm closure, industry and quarter dummies in the first stage regression. The danger with such a strategy is that these excluded interactions might be weak instruments, i.e. show a low partial correlation with unemployment. However, the F-statistics reported at the bottom of each panel demonstrate otherwise, they are above 60 for the first specification and above 100 in the second.

The rationale behind our identification strategy is that, as shown in Del Bono and Weber (2008), individual unemployment in Austria is subject to significant seasonal and industry-specific variation which is largely due to demand factors. This justifies the use of a set of interactions between firm closure and time, industry and geographical effects as our instrument for unemployment. The main assumption we make here is that the direct effect of firm closure on fertility is independent of time, region or industry. ${ }^{12}$ This might not be a valid assumption if, for example, the direct cost of job displacement varies by industry because the amount of firm-specific human capital destroyed upon displacement is different in different sectors of the economy, and therefore career costs differ by industry. We think this would be a concern if we were to use a very detailed definition of industry, where each group could represent a set of firms with similar human

\footnotetext{
${ }^{11}$ We have data for nine years, six regions and four industries (manufacturing, sales, transport and services).

${ }^{12}$ Note, that the same time (year and quarter), industry and region dummies are in the main fertility regression as well.
} 
capital requirements, wage structure and career opportunities. As we adopt here a very broad definition of industry, and distinguish among very large aggregates (manufacturing, sales, transport and services), we think this is not an issue, and that industry-specific variation in the effects of firm closure on fertility is mainly demand-led and the result of variation in unemployment rates.

Our identification strategy is based on a set of instruments given by the interaction between two exogenous variables which are separately controlled for in the main equation. An early example of a similar approach is to be found in Lemieux and Card (2001), who investigate the separate effects of veteran status and education on earnings using as an instrument for education the interaction between veteran status and father's education, where father's education is controlled for in the main equation. More recently, Chevalier et al. (2013) analyse the impact of family income on children's schooling using the interaction between father's union status and occupation as instruments (the latter two variables are included as separate regressors in the main equation on children schooling) for family income.

Once we take into account the endogeneity of unemployment our results change. In all specifications, the coefficient on firm closure remains negative, it becomes larger in magnitude, and it is in most cases significant. The coefficient of unemployment changes sign (becomes positive) and becomes insignificantly different from zero in all our specifications. In Panel A effect of unemployment incidence is very imprecisely estimated, but generals smaller in magnitude than the effect of firm closure. In Panel B, the effects of unemployment duration get very close to zero and have only negligible influence on fertility. This indicates that, when comparing displaced women according to their unemployment experience, there are no fertility differences according to the incidence and duration of unemployment. The only negative effect comes through the job loss experience per se. This is consistent with the evidence in Del Bono et al. (2012), who interpret the effects of job displacement on fertility in terms of employability and career effects. The results are robust to different specifications, as can be seen in Columns 3 to 
6.

In Table 4 we provide further evidence that career and employment considerations are the main mechanism through which job displacement affects fertility. Here we separate our sample into two groups: women with average wage growth below $5 \%$ and those with average annual wage growth above $5 \%$ in the last 3 years before displacement $(5 \%$ is roughly the median average growth rate of wages before displacement). The latter group should include more women in career-oriented jobs, for whom the direct effect of job displacement should be more important. Panel A reports results obtained by estimating a model in which only unemployment is included in the fertility equation (as seen in equation (1)), while Panel B includes also the firm closure dummy (as seen in equation (2)). For reasons of space we report results using only the first definition of unemployment, i.e. whether the woman has experienced any unemployment in the year after the reference date, and only for fertility after six years. The 2SLS models are estimated in the same way as before.

As we can see from Panel A, there is little difference in the effect of unemployment incidence on fertility for these two groups in the OLS regressions. This result changes, however, when we consider 2SLS estimates. This shows that the negative effect of unemployment as identified by firm closures is much larger for women with a steeper wage profile. The results in Panel B, which report the separate effects of firm closure and unemployment, again show that unemployment has a significant negative effect on fertility in the OLS regressions, and that this effect is not different between the two groups of women. The 2SLS, by contrast, reveal no significant impact of unemployment for both groups, and suggest a relatively stronger effect of firm closure for career-oriented women although this is not precisely estimated. 


\section{Conclusions}

In this paper we have shed new light on the impact of labor market instability and unemployment on women's fertility decisions. Our analysis shows that unemployment is highly negatively correlated to fertility rates of Austrian white-collar women. However, if we separate the effect of job loss from that of unemployment - taking the endogeneity of unemployment into account with a suitable IV strategy, we find that the direct impact of unemployment disappears but the job loss channel remains strongly significant. These results are compatible with a model of fertility which does not stress the income loss due to unemployment, but in which career and job considerations are more important.

We conclude that, while being easily available in typical datasets, unemployment is only an imperfect measure of the type of labor market issues which are relevant for fertility decisions. To understand trends in fertility across countries we must also look at other indicators such as the prevalence of temporary contracts, or the difficulty for young workers to enter the regular labor market. 


\section{References}

Adsera, A., 2005. Vanishing children: From high unemployment to low fertility in developed countries. American Economic Review Papers and Proceedings 95, 189-193.

Adsera, A., 2011. Where are the babies? Labor market conditions and fertility in europe. European Journal of Population 27, 1-32.

Adsera, A., Menendez, A., 2011. Fertility changes in Latin America in the context of economic uncertainty. Population Studies 65/1, 37-56.

Ahn, N., Mira, P., 2002. A note on the changing relationship between fertility and female employment rates in developed countries. Journal of Population Economics 15, 667682.

Bettio, F., Villa, P., 1998. A Mediterranean perspective on the break-down of the relationship between participation and fertility. Cambridge Journal of Economics 22, $131-171$.

Butz, W., Ward, M., 1979. The emergence of countercyclical US fertility. American Economic Review 49, 318-328.

Chevalier, A., Harmon, C., O'Sullivan, V., Walker, I., 2013. The impact of parental income and education on the schooling of children. IZA Journal of Labor Economics 2, doi:10.1186/2193-8997-2-8.

De la Rica, S., 2005. Career planning in Spain: Do fixed-term contracts delay marriage and parenthood? Review of Economics of the Household 3, 49-73.

Dehejia, R., Lleras-Muney, A., 2004. Booms, busts, and babies' health. Quarterly Journal of Economics 119, 1091-1130.

Del Bono, E., Weber, A., 2008. Compensating wage differentials and seasonal employment in austria: Evidence from administrative data. Journal of Labor Economics 26 (1), 181-221. 
Del Bono, E., Weber, A., Winter-Ebmer, R., 2012. Clash of career and family: Fertility decisions after job displacement. Journal of the European Economic Association 10.

Dustmann, C., Meghir, C., 2005. Wages, experience and seniority. Review of Economic Studies $72,77-108$.

Eliason, M., Storrie, D., 2006. Lasting or latent scars? Swedish evidence on the long-term effects of job displacement. Journal of Labor Economics 24, 831-857.

Engelhardt, H., Prskawetz, A., 2004. On the changing correlation between fertility and female employment over space and time. European Journal of Population 20, 35-62.

Gonzalez, M.-J., Jurado-Guerrero, T., 2006. Remaining childless in affluent economies: A comparison of France, West Germany, Italy and Spain, 1994-2001. European Journal of Population 22, 317-352.

Gutierrez-Domenenech, M., 2008. The impact of the labour market on the timing of marriage and births in spain. Journal of Population Economics 21, 83-110, 10.1007/s00148005-0041-z.

Heckman, J., Willis, R., 1975. Estimation of a stochastic model of reproduction: An econometric approach. In: Terleckyj, N. (Ed.), Household production and consumption. Columbia University Press, New York.

Kohler, H.-P., Kohler, I., 2002. Fertility decline in Russia in the early and mid 1990s: The role of economic uncertainty and labour market crises. European Journal of Population $18,233-262$.

Kravdal, O., 2002. The impact of individual and aggregate unemployment on fertility in Norway. Demographic Research 6/5, 263-294.

Kreyenfeld, M., 2010. Uncertainties in female employment careers and the postponement of parenthood in Germany. European Sociological Review 26/3, 351-366. 
Lemieux, T., Card, D., 2001. Education, earnings, and the 'Canadian G.I. Bill'. The Canadian Journal of Economics 34(2), 313-344.

Meron, M., Widmer, I., Shapiro, D., 2002. Unemployment leads women to postpone the birth of their first child. Population 57, 301-330.

Perry, C., 2003. How do female earnings affect fertility decisions, mimeo, MIT.

Ranjan, P., 1999. Fertility behaviour under income uncertainty. European Journal of Population 15, 25-43.

Sobotka, T., Skirbekk, V., Philipov, D., 2011. Economic recession and fertility in the developed world. Population and Development Review 37(2), 267-306.

Zweimüller, J., Winter-Ebmer, R., Lalive, R., Kuhn, A., Wuellrich, J.-P., Ruf, O., Büchi, S., 2009. Austrian Social Security Database. Tech. Rep. Working Paper 0903, NRN: The Austrian Center for Labor Economics and the Analysis of the Welfare State. 

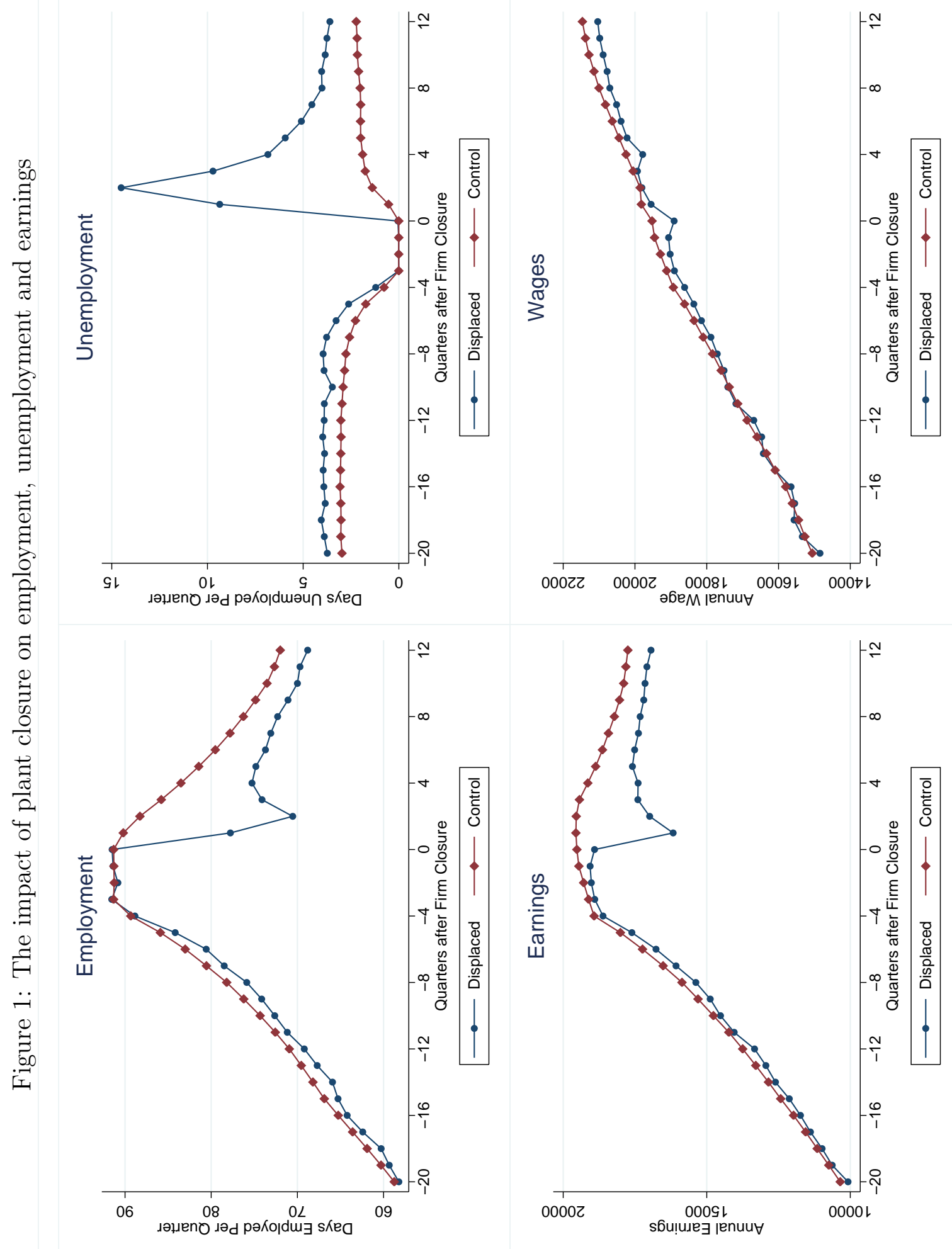

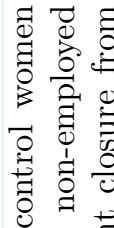
羊茧 ธี के

过

$\because$.

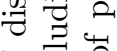

पै

记

을. 욤

ฮี

$\Xi 2$

送

구 궁

वै

柋莺

पै

$\dot{\overline{0}} \stackrel{0}{0}$

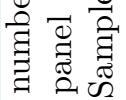

\&o

究

我

๑ 80.

过言

矛

우워

of

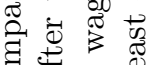

营

물

焉元萨

颉

-

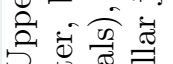

.

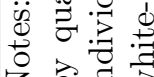




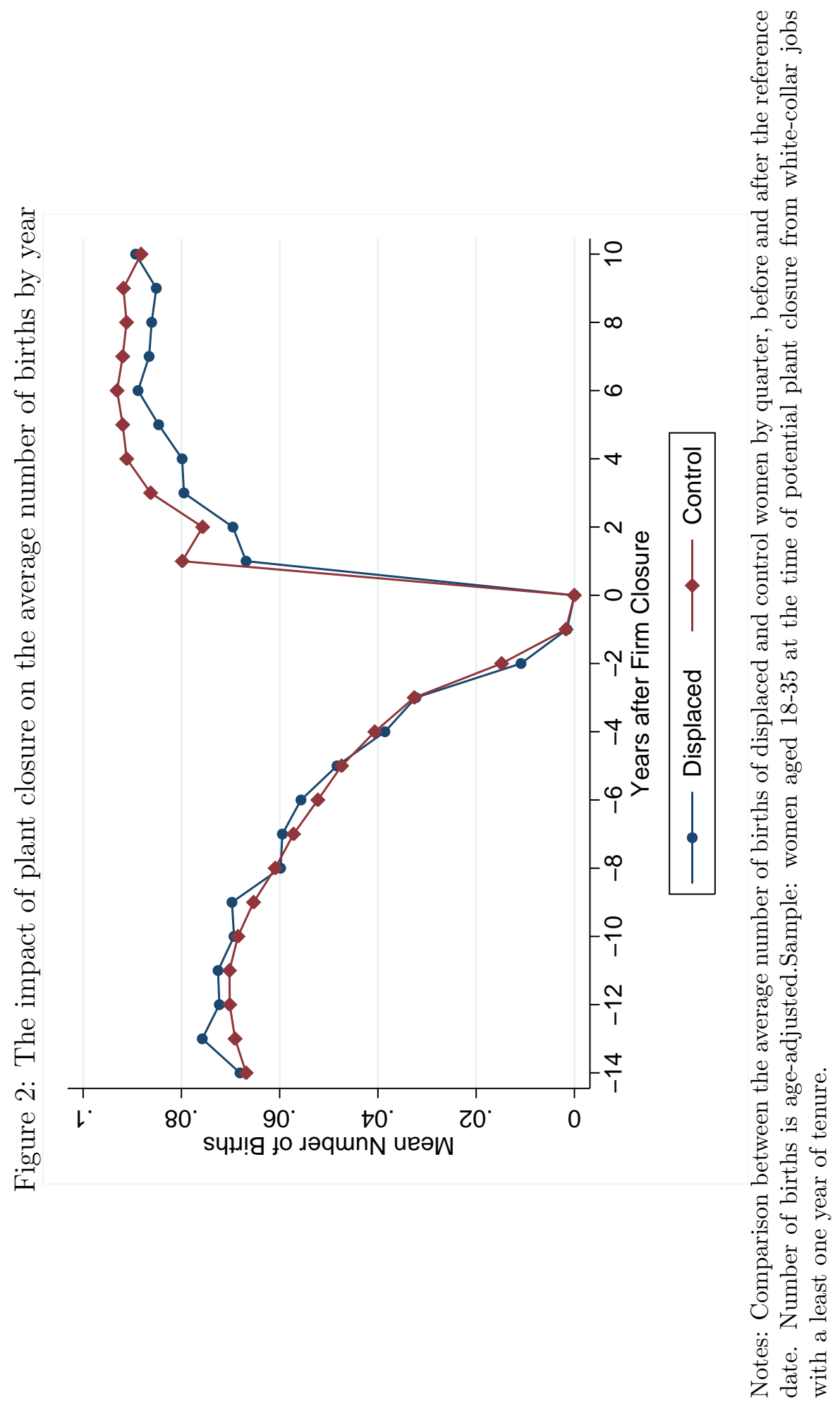


Table 1: Individual Characteristics

\begin{tabular}{lcccccc}
\hline \hline & & & & & & \\
& Control group & Displaced group & All \\
\hline & & & & & & \\
& mean & sd. & mean & sd. & mean & sd. \\
Age & 27.07 & 4.67 & 27.28 & 4.65 & 27.08 & 4.67 \\
Austrian & 0.98 & 0.14 & 0.97 & 0.18 & 0.98 & 0.14 \\
Experience (months) & 103.80 & 53.14 & 105.98 & 53.99 & 103.89 & 53.18 \\
Tenure (months) & 49.50 & 37.43 & 43.22 & 35.16 & 49.26 & 37.36 \\
Age at labor market entry & 16.90 & 2.42 & 16.87 & 2.60 & 16.90 & 2.43 \\
Apprenticeship & 0.35 & 0.48 & 0.41 & 0.49 & 0.36 & 0.48 \\
Earnings 1 year before & 734.10 & 273.52 & 720.11 & 292.92 & 733.55 & 274.32 \\
Earnings 2 years before & 696.00 & 262.51 & 688.05 & 279.47 & 695.69 & 263.20 \\
Earnings 3 years before & 606.77 & 307.13 & 594.02 & 326.25 & 606.27 & 307.91 \\
Earnings 4 years before & 536.71 & 322.00 & 526.29 & 332.20 & 536.31 & 322.41 \\
\% employment 2 years before & 0.93 & 0.20 & 0.91 & 0.22 & 0.93 & 0.20 \\
\% employment 3 years before & 0.83 & 0.33 & 0.80 & 0.35 & 0.82 & 0.34 \\
\% employment 4 years before & 0.75 & 0.39 & 0.73 & 0.40 & 0.75 & 0.39 \\
Number of previous children & 0.38 & 0.71 & 0.42 & 0.72 & 0.39 & 0.71 \\
\% unemployment 1 year after & 0.02 & 0.08 & 0.11 & 0.21 & 0.02 & 0.09 \\
Any unemployment 1 year after & 0.06 & 0.25 & 0.33 & 0.47 & 0.08 & 0.26 \\
Births next 3 years & 0.19 & 0.44 & 0.17 & 0.41 & 0.19 & 0.43 \\
Births next 6 years & 0.43 & 0.68 & 0.38 & 0.65 & 0.43 & 0.68 \\
Observations & 157784 & & 6431 & & 164215 & \\
\hline & & & & & & \\
\hline
\end{tabular}

Notes: Variable means, standard deviations in parentheses. Displaced group includes women aged 18 to 35 with at least one year of tenure in closing firms at the closure date. Control group is a $5 \%$ random subsample of women aged 18 to 35 with at least one year of tenure in firms that do not close within the next 2 years of the reference date. The outcome includes the number of children born between 6 months and 3 (or 6) years after the reference date. None of the differences between control group and displaced group are statistically significant. 
Table 2: Effects of unemployment on fertility

\begin{tabular}{|c|c|c|c|c|}
\hline & \multicolumn{2}{|c|}{$\underline{\text { OLS }}$} & \multicolumn{2}{|c|}{$\underline{2 S L S}$} \\
\hline & $\begin{array}{c}\text { Births next } \\
3 \text { years }\end{array}$ & $\begin{array}{c}\text { Births next } \\
6 \text { years }\end{array}$ & $\begin{array}{c}\text { Births next } \\
3 \text { years }\end{array}$ & $\begin{array}{c}\text { Births next } \\
6 \text { years }\end{array}$ \\
\hline \multicolumn{5}{|c|}{ Panel A: any unemployment in the first year } \\
\hline Unemployment & $\begin{array}{c}-0.0330^{* *} \\
(0.0039)\end{array}$ & $\begin{array}{c}-0.0680^{* *} \\
(0.0062)\end{array}$ & $\begin{array}{c}-0.0667^{*} \\
(0.0207)\end{array}$ & $\begin{array}{c}-0.1222^{* *} \\
(0.0321)\end{array}$ \\
\hline t-test & & & 77.033 & 77.03 \\
\hline $\mathrm{R}^{2}$ & 0.0365 & 0.0814 & 0.0351 & 0.0810 \\
\hline Observations & 164,215 & 164,215 & 164,215 & 164,215 \\
\hline \multicolumn{5}{|c|}{ Panel B: \% unemployment in the first year } \\
\hline Unemployment & $\begin{array}{c}-0.0003^{*} \\
(0.0001)\end{array}$ & $\begin{array}{c}-0.0010^{* *} \\
(0.0002)\end{array}$ & $\begin{array}{c}-0.0018^{*} \\
(0.0006)\end{array}$ & $\begin{array}{c}-0.0033^{* *} \\
(0.0009)\end{array}$ \\
\hline t-test & & & 83.83 & 83.83 \\
\hline $\mathrm{R}^{2}$ & 0.0352 & 0.0810 & 0.0342 & 0.0801 \\
\hline Observations & 164,215 & 164,215 & 164,215 & 164,215 \\
\hline
\end{tabular}

Notes: Estimations from OLS and 2SLS regressions, where the unemployment variable is instrumented by firm closure dummy (t-statistics shown). Unemployment is measured by an indicator for being unemployed in the first year since the reference date (Panel A) and by the percentage of time unemployed in the first year after the reference date (Panel B). Displaced group includes white-collar women aged 18-35 with at least one year of tenure in closing firms at the closure date. Control group is a $5 \%$ random subsample of white-collar women aged 18-35 with at least one year of tenure in firms that do not close within the next 2 years of the reference date. The outcome variable births next 3 (6) years measures the number of children born between 6 and 36 (72) months after the reference date. Covariates include: maternal age and its square, tenure, experience, indicator for apprenticeship education, previous earnings, previous employment, number of previous children, year, quarter, region and industry dummies. Robust standard errors clustered at the individual level reported. Symbols:** significant at 1\%; significant at $5 \%$. 
Table 3: Pure displacement versus unemployment effect on fertility

\begin{tabular}{|c|c|c|c|c|c|c|}
\hline & \multicolumn{2}{|c|}{$\underline{\text { OLS }}$} & \multicolumn{2}{|c|}{$\underline{\text { 2SLS Model } 1}$} & \multicolumn{2}{|c|}{$\underline{\text { 2SLS Model } 2}$} \\
\hline & $\begin{array}{l}\text { Births next } \\
3 \text { years }\end{array}$ & $\begin{array}{l}\text { Births next } \\
6 \text { years }\end{array}$ & $\begin{array}{c}\text { Births next } \\
3 \text { years }\end{array}$ & $\begin{array}{c}\text { Births next } \\
6 \text { years }\end{array}$ & $\begin{array}{c}\text { Births next } \\
3 \text { years }\end{array}$ & $\begin{array}{l}\text { Births next } \\
6 \text { years }\end{array}$ \\
\hline \multicolumn{7}{|c|}{ Panel A: any unemployment in the first year } \\
\hline Firm closure & $\begin{array}{c}-0.0088 \\
(0.0053) \\
-0.0318^{* *} \\
(0.0040)\end{array}$ & $\begin{array}{c}-0.0142 \\
(0.0083) \\
-0.0661^{* *} \\
(0.0063)\end{array}$ & $\begin{array}{c}-0.0225 \\
(0.0120) \\
0.0224 \\
(0.0456)\end{array}$ & $\begin{array}{c}-0.0424^{*} \\
(0.0191) \\
0.0457 \\
(0.0692)\end{array}$ & $\begin{array}{c}-0.0291^{*} \\
(0.0126) \\
0.0458 \\
(0.0456)\end{array}$ & $\begin{array}{c}-0.0377^{*} \\
(0.0194) \\
0.0271 \\
(0.0708)\end{array}$ \\
\hline $\begin{array}{l}\text { F-stat } \\
\mathrm{R}^{2} \\
\text { Observations }\end{array}$ & $\begin{array}{c}0.0356 \\
164,215\end{array}$ & & $\begin{array}{c}71.65 \\
0.0345 \\
164,215\end{array}$ & $\begin{array}{c}71.65 \\
0.0800 \\
164,215\end{array}$ & $\begin{array}{c}67.55 \\
0.0333 \\
164,215\end{array}$ & $\begin{array}{c}67.55 \\
0.0802 \\
164,215\end{array}$ \\
\hline \multicolumn{7}{|c|}{ Panel B: \% unemployment in the first year } \\
\hline Unemployment & $\begin{array}{c}-0.0147^{*} \\
(0.0053) \\
-0.0002 \\
(0.0001)\end{array}$ & $\begin{array}{c}-0.0220^{*} \\
(0.0083) \\
-0.0010^{* *} \\
(0.0002)\end{array}$ & $\begin{array}{c}-0.0178 \\
(0.0115) \\
0.0001 \\
(0.0011)\end{array}$ & $\begin{array}{c}-0.0356^{*} \\
(0.0176) \\
0.0005 \\
(0.0017)\end{array}$ & $\begin{array}{c}-0.0226^{*} \\
(0.0114) \\
0.0006 \\
(0.0011)\end{array}$ & $\begin{array}{c}-0.0318 \\
(0.0175) \\
0.0001 \\
(0.017)\end{array}$ \\
\hline $\begin{array}{l}\text { F-stat } \\
\mathrm{R}^{2} \\
\text { Observations }\end{array}$ & $\begin{array}{c}0.0352 \\
164,215 \\
\end{array}$ & $\begin{array}{c}0.0810 \\
164,215 \\
\end{array}$ & $\begin{array}{c}108.73 \\
0.0353 \\
164,215 \\
\end{array}$ & $\begin{array}{r}108 \\
0.0 \\
164\end{array}$ & $\begin{array}{c}107.86 \\
0.0349 \\
164,215 \\
\end{array}$ & $\begin{array}{c}107.86 \\
0.0808 \\
164,215 \\
\end{array}$ \\
\hline \multicolumn{7}{|c|}{$\begin{array}{l}\text { Notes: Estimations from OLS and 2SLS regressions, where the unemployment variable is instrumented by firm } \\
\text { closure interacted with } 8 \text { year, } 3 \text { quarter, } 3 \text { industry, and } 5 \text { region dummies (Model } 1 \text { ), as well plant closure } \\
\text { interacted with industry and quarter dummies only (Model 2). F-statistics refer to the joint significance of } \\
\text { the excluded instruments in the first stage regression. Unemployment is measured by an indicator for being } \\
\text { unemployed in the first year since the reference date (Panel A) and by the percentage of time unemployed in } \\
\text { the first year after the reference date (Panel B). Displaced group includes white-collar women aged } 18-35 \text { with } \\
\text { at least one year of tenure in closing firms at the closure date. Control group is a } 5 \% \text { random subsample of } \\
\text { white-collar women aged } 18-35 \text { with at least one year of tenure in firms that do not close within the next } 2 \\
\text { years of the reference date. The outcome variable births next } 3 \text { (6) years measures the number of children born } \\
\text { between } 6 \text { and } 36 \text { ( } 72 \text { ) months after the reference date. Covariates include: maternal age and its square, tenure, } \\
\text { experience, indicator for apprenticeship education, previous earnings, previous employment, number of previous } \\
\text { children, year, quarter, region and industry dummies. Robust standard errors clustered at the individual level } \\
\text { reported. Symbols:** significant at } 1 \% \text {; significant at } 5 \% \text {. }\end{array}$} \\
\hline
\end{tabular}




\section{OLS}

earn. growth $<5 \%$ earn. growth $>5 \%$ earn. growth $<5 \%$ earn. growth $>5 \%$

Birth next 6y Births next 6y Births next 6y Birth next 6y

Panel A: unemployment effects only

$\begin{array}{lcccc}\text { Unemployment } & -0.0686^{* *} & -0.0705^{* *} & -0.0966^{* *} & -0.1382^{* *} \\ & (0.0099) & (0.0097) & (0.0483) & (0.0529) \\ \text { F-stat } & & & 52.94 & 49.55 \\ \mathrm{R}^{2} & 0.1054 & 0.066 & 0.1053 & 0.0654 \\ \text { Observations } & 65,119 & 75,549 & 65,119 & 75,549\end{array}$

Panel B: firm closure and unemployment effects

\begin{tabular}{lcccc} 
Firm closure & -0.0077 & -0.0167 & -0.0155 & -0.0409 \\
& $(0.0131)$ & $(0.0128)$ & $(0.0281)$ & $(0.0299)$ \\
Unemployment & $-0.0415^{* *}$ & $-0.0683^{* *}$ & -0.0379 & 0.0334 \\
& $(0.0067)$ & $(0.0099)$ & $(0.0951)$ & $(0.1153)$ \\
F-stat & & & 35.99 & 27.32 \\
$\mathrm{R}^{2}$ & 0.047 & 0.066 & 0.105 & 0.064 \\
Observations & 65,119 & 75,549 & 65,119 & 75,549 \\
\hline
\end{tabular}

Notes: Estimations from OLS and 2SLS regressions by subgroups defined on the basis of pre-displacement wage growth. Panel A presents the effect of unemployment. In this panel the 2SLS results are obtained using a dummy for firm closure as an instrument, as also shown in Table 2 for the entire sample. Panel B presents estimates of the separate effects of firm closure and unemployment. Here the 2SLS results are obtained using interactions between firm closure and 8 years, 3 quarters, 5 regions and 3 industry dummies, as per Model 1 in Table 3. F-statistics refer to the significance of the excluded instruments in the first stage regression. Unemployment is measured by an indicator for being unemployed in the first year since the reference date. Covariates include: maternal age and its square, tenure, experience, indicator for apprenticeship education, previous earnings, previous employment, number of previous children, year, quarter, region and industry dummies. Robust standard errors clustered at the individual level reported. Symbols:** significant at $1 \%$; $^{*}$ significant at $5 \%$. 